\title{
Treatment of Drinking Water in Economical Cost Perspective
}

\author{
M Badar ${ }^{* 1}$, M Ahsan Zia ${ }^{2}$, Muhammad Idrees ${ }^{3}$, Fatima Batool ${ }^{4}$, Hafiz RehanIqbal ${ }^{5}$ \\ ${ }^{1}$ Department of Environmental Management, National College of Business Administration and Economics, Lahore \\ ${ }^{2}$ Department of Management Sciences, University of Sargodha, Lahore Campus \\ ${ }^{3}$ Departement of Computer Science \& Engineering, University of Engineering and Technology, Lahore \\ ${ }^{4}$ Centre of Excellence in Molecular Biology, University of the Punjab. Lahore \\ ${ }^{5}$ Departement of Physics, University of Engineering and Technology, Lahore
}

\begin{abstract}
It is observed that most economical way in treating the drinking water for humans with coagulation treatment cost is Rs.1.25 per litre calculated in case of open surface water but only Rs.0.15 cost for ground and water storage tanks samples, after treatment it is sure water is safe for drinking purpose. But boiling treatment of drinking water is not economical as compare to coagulation treatment because it covers the Rs. 2.5 to Rs. 1.0 it depends on nature of water quality to treat. This cost was applicable and useful for human's drinking water treatment and save the medical treatment cost from suffering the painful water borne diseases such as cholera and diarrhoea.

Aluminium sulphate is coagulated which economical but with low price available and we must use it for canal water treatment because 5 to 10 percent toxins are present. In case of ground water and storage water tanks, treatment we no need coagulant we just need boiling of drinking water then it is sure that toxins and other organic material vaporized and drinking water free of low toxicity and safe to health.
\end{abstract}

Keywords-Toxins, Water Treatment, Economical Method, Cost, Boiling.

\section{INTRODUCTION}

Water is totally vital for the survival, growth and protection for human life; these reasons make it a unique commodity in this world. But, approximately one billion persons in this world not have easily access with potable water, especially those people breathing in third world countries. Water crisis has obsessed on these regions where threatening the quality of life in the developing world. According to statement of the United Nations on Human Development Report, approximately in one year, 1.4 million children expire due to unavailable and unclean drinking water, and 3.6 million people expire every year due to water-borne diseases, including the $84 \%$ are children and $98 \%$ are adults, those who living in the developing countries. It is Clear, it is a key health issue in this world currently and it must be needed some special attention for saving the life of the millions people due to failing of survival from preventable diseases $[1,2]$.

Waterborne diseases create the mainstream of illnesses that is reason of distress and death in under developing countries. In developing states improved system of water and sanitation can contribute to make half of all people are suffering and it is mostly due to the countless diseases that outcome from unsafe drinking water. According to an article concerning with water, health and hygiene give the information 2.4 million approximately deaths worldwide could be banned per year if every person with good practiced on hygiene system and had fresh water for drinking. The sicknesses that outcome from drinking of infected water include typhoid, malaria, cholera, Guinea worm, amoebas, Giardia, and other pests; but the extreme disease caused by under standard water by quality [3].

Pathogenic microbes, such as protozoa and bacteria in contaminated water may be transmitted to a person through in taking the drinking water and other uses of drinking water like washing and eating foods that have been cooked from the contaminated water. The persons are infected with the pathogenic microorganisms present in the water and grow a waterborne disease. Not only waterborne diseases, there are also effected the water-washed diseases which can affect the millions of person. Water-washed diseases include those illnesses that are removed by simply washing with water [4].

In favour to health, water is important for proper hygiene process. Just washing the hands with soap, then water can reduce the threat of common diarrhoea by the almost $50 \%$ and other respiratory and skin infections. Washing hands with soap is an important tool to prevent the spreading of diseases which caused by drinking water with faeces contamination of eggs carrying and the resulting situation can see in form of fever, vomiting, and nausea, and diarrhoea with their major symptoms. Hand washing can reduce level of neonatal deaths if performed at post-delivery [5].

In this present study, we want to calculate the total drinking water treatment cost in Pakistanirupees byusing the different water treatment methods under our study area.

\section{MATERIALS AND METHODS}

Analytical methods[6]

Parameters are tested as

1. turbidity and colour were analysed on a spectrophotometer, 
2. $\mathrm{pH}$ was determined by using a $\mathrm{pH}$ meter ,

3. Removing cyanotoxins and cyanobacteria cells was examined by using the Utermöhl method

\section{Preparation of Coagulants solutions}

\section{a. Aluminium Sulphate (AS)}

It is Aluminium sulphate as chemical formula $\mathrm{Al}_{2}$ $\left(\mathrm{SO}_{4}\right)_{3} \cdot 14 \mathrm{H}_{2} \mathrm{O}$. Solution of different concentration used as $(5,10,15,20,25,30(\mathrm{mg} / \mathrm{l}))$ in this study [12].

\section{b. Conventional Coagulation Experiments}

At room temperature $\left(27^{\circ} \mathrm{C}\right)$, Coagulation experiments were performed using two jar test equipment. It is calculated the performances efficiency of aluminium sulphate in different concentration (mentioned above) as coagulation process for removing the toxins from drinking samples of water [12].

\section{Boiling}

Take the 5 litre volume vessel of $2 \mathrm{~kg}$ weight and steel manufactured; put the different samples of water as mentioned above. A temperature measuring thermometer put inside vessel for measuring the temperature on different interval of times as $2 \mathrm{~min}, 3 \mathrm{~min}$ and $5 \mathrm{~min}[12]$.

\section{RESULTS}

Cost-Benefit Analysis by using the chemical coagulation process

Aluminium sulphate is coagulated which economical but with low price available and we must use it for canal water treatment because 5 to 10 percent toxins are present and in case of ground water and storage water tanks, treatment we no need coagulant we just need boiling of drinking water then It is sure that toxins and other organic material vaporized and drinking water free of low toxicity and safe to health.

It is observed in table- 1 that most economical way in treating the drinking water for humans with coagulation treatment cost is Rs.1.25 per litre calculated in case of open surface water but only Rs.0.15 cost for ground and water storage tanks samples, after treatment it is sure water is safe for drinking purpose.

Table.1: Cost analysis of two different methods of treatment for Removing the toxins and disinfection of drinking water samples

\begin{tabular}{|l|c|}
\hline \multirow{2}{*}{ Water Samples } & $\begin{array}{l}\text { Water treatment Cost per } \\
\text { litter (in Pak Rupees) }\end{array}$ \\
\cline { 2 - 2 } & $\mathrm{Al}_{2}\left(\mathrm{SO}_{4}\right)_{3} \cdot 14 \mathrm{H}_{2} \mathrm{O}$ \\
\hline $\begin{array}{l}\text { Canal Drinking water } \\
\text { Treatment }\end{array}$ & $25 \mathrm{mg}(.05 \times 25=1.25 \mathrm{Rs})$. \\
\hline $\begin{array}{l}\text { storage tanks Water } \\
\text { Treatment }\end{array}$ & $10 \mathrm{mg}(.05 \times 10=0.5 \mathrm{Rs})$. \\
\hline $\begin{array}{l}\text { Ground Water } \\
\text { Treatment }\end{array}$ & $3 \mathrm{mg}(.05 \times 3=0.15 \mathrm{Rs})$. \\
\hline
\end{tabular}

Cost-Benefit Analysis by using the hot boiling process But boiling treatment of drinking water is not economical as compare to coagulation treatment because it needs only Rs.
2.5 to Rs. 1.0 per litter of drinking water but it depends on nature of water quality to treat. This cost was applicable and useful for human's drinking water treatment and save the medical treatment cost from suffering the painful water borne diseases such as cholera and diarrhoea.

Boiling process need at least five minus for effecting microbe's disinfection and chlorine needs the specific dose with no residue left because high dose of chlorine cause toxicity in humans.

Table.2: Cost analysis of two different methods of treatment for Removing the toxins and disinfection of drinking water samples

\begin{tabular}{|l|c|}
\hline \multirow{2}{*}{ Water Samples } & $\begin{array}{l}\text { Water treatment Cost per } \\
\text { litter (in Pak Rupees) }\end{array}$ \\
\cline { 2 - 2 } & Boiling \\
\hline $\begin{array}{l}\text { Canal Drinking water } \\
\text { Treatment }\end{array}$ & 5 min. $(.50 \times 5=2.5 \mathrm{Rs})$. \\
\hline $\begin{array}{l}\text { storage tanks Water } \\
\text { Treatment }\end{array}$ & 3 min. $(.50 \times 3=1.5 \mathrm{Rs})$. \\
\hline Ground Water Treatment & 2 min. $(.50 \times 2=1 \mathrm{Rs})$. \\
\hline
\end{tabular}

In case of cattle and buffaloes, this study give the idea that open surface water can treat with chlorine, it is important for their normal health and better economic growth for meat and milk production because their drinking water can free from microbial contamination with very low cost of treatment of drinking water . Low cast idea given in table 2 for treatment of drinking water of large volume for animals. Cost-Benefit Analysis by using the chemical chlorination process

As shown in table-3, with using the ferric chloride, the treatment cost less as Rs. 1.00 per liter for canal water and Rs. 0.10 to 0.04 per liter in ground and storage tanks water for animal's drinking.

Microbial contamination in water is a serious threat to all living organisms, including plans, animals and human beings it must need disinfection process properly and we test here two different economical methods. First use chlorine and second use boiling, both are reliable but make sure more economical depend on situation because boiling method must be needed that follow the complete process either boiling or chlorine (Dubois M, et al., 2010) (DWI, 2010).

Table.3: Cost analysis of $\mathrm{Cl}_{2}$ method of microbe's disinfection for treatment of drinking water samples

\begin{tabular}{|c|l|}
\hline Water samples & $\begin{array}{l}\text { Water treatment Cost per } \\
\text { litter (in Pak Rupees) of } \\
\text { drinking water for microbes } \\
\text { disinfections purposes as } \\
\text { chemical Cl }\end{array}$ \\
\hline & $\mathrm{FeCl}_{3} \cdot 6 \mathrm{H}_{2} \mathrm{O}$ \\
\hline $\begin{array}{c}\text { Canal Drinking water } \\
\text { Treatment }\end{array}$ & $3 \mathrm{mg}(.05 \times 3=0.15 \mathrm{Rs})$. \\
\hline
\end{tabular}




\begin{tabular}{|c|c|}
\hline $\begin{array}{c}\text { storage tanks Water } \\
\text { Treatment }\end{array}$ & $1 \mathrm{mg}(.05 \times 1=0.05 \mathrm{Rs})$. \\
\hline $\begin{array}{c}\text { Ground Water } \\
\text { Treatment }\end{array}$ & $0.8 \mathrm{mg}(.05 \times 0.8=0.04 \mathrm{Rs})$. \\
\hline
\end{tabular}

\section{Comparison cost analysis of water treatment methods}

Cost effective drinking water treatment methods (coagulation, boiling and Chlorination) developed for humans and animals (cows and buffaloes) was given in very low cost as from Rs.0.15 to Rs. 0.75 as shown in table-3, in this study for better health and safe drinking which is affordable for common people. But boiling treatment of drinking water is not economical as compare to coagulation treatment because it covers the Rs. 2.5 to Rs. 1.0. After treatment, it is sure to safe water for drinking and domestic purpose. The health of cows and buffaloes had important role in development of rural area economics. So, they need large volume of water for drinking, present cost is very effective for water treatment.

By applying the billing method for drinking water which had not low expense as compare to coagulation as see in table 1, but expose to the toxicity level negligible on this time and as result after some years passed high level concentration of toxins will be present in our body or in our blood stream then it is also possible we are suffering from a serious liver problem which will be high cost medical treatment with facing the extra tension.

Table .4: Cost Analysis of Two Different Methods of Treatment for Removing the Toxins and Disinfection of Drinking Water Samples

\begin{tabular}{|c|c|c|c|}
\hline \multirow{2}{*}{$\begin{array}{c}\text { Water } \\
\text { samples }\end{array}$} & \multicolumn{3}{|l|}{$\begin{array}{l}\text { Water treatment Cost per liter (in Pak } \\
\text { Rupees =Rs.) }\end{array}$} \\
\cline { 2 - 4 } & $\mathbf{A l}_{\mathbf{2}}\left(\mathbf{S O}_{\mathbf{4}}\right)_{\mathbf{3}} \mathbf{\cdot} \mathbf{1 4}_{\mathbf{2}} \mathbf{O}$ & $\mathbf{F e C l}_{\mathbf{3}} \mathbf{. 6} \mathbf{H}_{\mathbf{2}} \mathbf{O}$ & Boiling \\
\hline $\begin{array}{c}\text { Canal } \\
\text { Drinking } \\
\begin{array}{c}\text { Water } \\
\text { Treatment }\end{array}\end{array}$ & 1.25 & 1.1 & 2.5 \\
\hline $\begin{array}{c}\text { Storage Tanks } \\
\text { Water } \\
\text { Treatment }\end{array}$ & 0.5 & 0.7 & 1.5 \\
\hline $\begin{array}{c}\text { Ground } \\
\text { Water } \\
\text { Treatment }\end{array}$ & 0.15 & 0.21 & 1 \\
\hline
\end{tabular}

\section{DISCUSSIONS}

All the world population are concerned about quality of drinking water along with economical or cheaper way, so all conventional methods can be used under specific limits and parameters for removing the hazardous material as microbes toxins from drinking water sources[7].

The conventional drinking water treatment methods (coagulation, chlorination $\&$ boiling) are needed to modify the disinfection of microbes and removing their toxins from water sources with very low cost; this is the main objective of this study. For this purpose, Chlorine is used as disinfectant but new thing in this study is the specific dose is determined for three different samples of drinking water with no residue of chlorine left in treated water because it can cause cancer in humans. Contaminated canal water for drinking purpose needs dose $3 \mathrm{mg} / \mathrm{l}$ of chlorine for complete disinfection without residue and $1.5 \mathrm{mg} / \mathrm{l}$ dose of chlorine is required for treating the drinking water of storage tanks without any toxicity causing by chlorine residue[ 8,9$]$.

Hygiene information is very important for better utilization of safe water drinking. Moreover, the procedure involved for drinking water management system and how to store at the domestic level, it is need to increase knowledge of individual and community about the awareness of water hygiene and public health. The awareness of this type is very useful to achieve and support to the final objective of research about covered and piped potable water for the World's population, then it will help to reduce water borne disease like diarrhoea and cholera in the our community.

Chemical coagulation as treatment of drinking water with Aluminum Sulphate and $\mathrm{FeCl}_{3}$ was very effective for removing toxins (shiga toxin, Botulinum toxin and Microcystins). Studies show that $90-98 \%$ toxins remove from drinking water samples by using the coagulant but boiling of drinking water treatment method remove $95 \%$ only[10, 11, 12].

Additionally, face washing can prevent and reduce the eye infections as Tacoma, the greatest reason of infectious of blindness across the world. Trachoma is a bacteriological infection disease of the eye produced by the bacteria Chlamydia trachomatis. Some of the symptoms related with Tacoma contain the following: cloudy cornea, release from the eye, swelling of lymph nodes just in front of the ears, turned-in eyelashes, and swollen eyelids. Tacoma spreads with direct contact of a contaminated object such as touch with a towel or makes the direct contact with the secretions of a infected parts of body such as nose, throat and eyes. Infection Prevention occurs by adopting the facial hygiene and then hand washing. Presently, there are about 8 million people cases of the blindness due to spreading of trachoma in the world, these transpiring mainly occur in Africa and Asia; it is widespread in the estimated 55 states of the world. Water also is used to wash the toilets, and further refining the hygiene system and stopping infections resulting from contamination of faecal matter. In final result, life needs to require the safe water for drinking and other use; therefore, countless kinds of diseases result from unsafe and unclean drinking water [13, 14].

Drive the results from research, the treatment of drinking water by coagulants like aluminium sulphate gives the method of toxin reduction in samples of water, but if tried to economical way as boiling it give help to reduce the concentration of toxins with low level along with microbes disinfections $[15,16]$. 


\section{CONCLUSION}

Remarkable results have given in treatment with coagulant aluminum sulphate, boiling and ferric chloride for toxins removing from samples. The results of study is showing the toxins and other contaminations can remove on cheaper way by using the chemical coagulation process only.

Next needs the improvement and follow up on chemical process for saving the energy during the manufacturing operations. In the process of filtration as final treatment was used the Granular Activated Carbon material which is proved very useful for maintaining the taste and natural smell of drinking water.

\section{REFERENCES}

[1] Anderson DM, Cembella AD, Hallegraeff GM. () Progress in understanding harmful algal blooms: paradigm shifts and new technologies for research, monitoring, and management. Annual Review of Marine Sci,.vol.4, pp.143-176, 2012.

[2] [2] B. Eikebrokk, T. Junha, and S.W. Østerhus. Water treatment by enhanced coagulation. TechneauBlanco J, Livramento F, Rangel IM. Amnesic shellfish poisoning (ASP) toxins in plankton and molluscs from Luanda Bay, Angola.Toxicon., vol. 55, pp. 541-546, 2006.

[3] Devlin RA, Campbell K, Kawatsu K, Elliott CT. Physical and immunoaffinity extraction of paralytic shellfish poisoning toxins from cultures of the dinoflagellateAlexandriumtamarense.Harmful Algae,vol. 10, pp.:542-548, 2011.

[4] Dotson, P. Westerhoff, and S.W. Krasner. Nitrogen enriches dissolved organic matter (DOM) isolates and their affinity to form emerging disinfection byproducts. Journal of Water Science and Technology, vol.60(1), pp. 135-143,2009.

[5] Dubois M, Demoulin L, Charlier C, Singh G, Godefroy SB, Campbell K, Elliott CT, Delahaut P Development of ELISAs for detecting domoic acid, okadaic acid, and saxitoxin and their applicability for the detection of marine toxins in samples collected in Belgium. Food AdditContam Part A Chem Anal Control Expo Risk Assess., vol. 27, pp. 859-868, 2010.

[6] Fux E, Smith JL, Tong M, Guzman L, Anderson DM. Toxin profiles of five geographical isolates of Dinophysis spp. From North and South America.Toxicon., vol. 57, pp. 275-287, 2011.

[7] G.S. Wang, Y.Ch. Deng, and T.F. Lin. Cancer risk assessment from trihalomethanes in drinking water. Science of the Total Environment.Vol. 387, pp. 86-95, 2007.

[8] Gerssen A, Mulder PPJ, de Boer J. Screening of lipophilic marine toxins in shellfish and algae: development of a library using liquid chromatography coupled to orbitrap mass spectrometry. Anal ChimActa., vol. 685, pp.176-185, 2011.
[9] Glibert PM, Anderson DM, Gentein P, Graneli E, Sellner KG.The global, complex phenomena of harmful algal blooms.Oceanography., vol. 18, pp.136147,2005 .

[10] McKaigeny, C. Hepatic Abscess: Case repot and review.Whst JEmergMed.,vol. 14(2), pp.154157,2013 .

[11]Pletinck A, Glorieux G, Schepers E, Cohen G, Gondouin B, Van Landschoot M, Eloot S, Rops A, Van de Voorde J, De Vriese A, van der Vlag J, Brunet $\mathrm{P}$, Van Biesen W, Vanholder R. Protein-Bound Uremic Toxins Stimulate Crosstalk between Leukocytes and Vessel Wall. J Am SocNephrol., vol. 5, pp.416-421, 2013.

[12] Poveda J, Sanchez-Nino MD, Glorieux G, Sanz AB, Egido J, Vanholder R, Ortiz A. (2014) p-Cresyl sulphate has pro-inflammatory and cytotoxic actions on human proximal tubular epithelial cells. Nephrol Dial Transplant, Jan,

[13] Van den Top HJ, Elliott CT, Haughey SA, Viarino N, van Egmond HP, Botana LM, Campbell K. Surface plasmon resonance biosensor screening method for paralytic shellfish poisoning toxins: a pilot interlaboratory study. Anal Chem., vol. 83, pp.42064213, 2011.

[14] Wiese M, D'Agostino PM, Mihali TK, Moffitt MC, Neilan BA. Neurotoxic alkaloids: saxitoxin and its analogs. Mar Drugs,vol. 8, pp.2185-2211, 2010.

[15] Yakes BJ, Prezioso S, Haughey SA, Campbell K, Elliott CT, DeGrasse SL. An improved immunoassay for detection of saxitoxin by surface plasmon resonance biosensors. Sensors Actuators BioChem., vol. 156, pp.:805-811, 2011. 